\title{
RISE IN 2017-2018 MEASLES MORBIDITY IN SERBIA AND NORTHWEST RUSSIA
}

\author{
V. Stoiljkovic ${ }^{a}$, M.A. Bichurina ${ }^{b}$, I.N. Lavrentieva ${ }^{b}$, S. Filipovic-Vignjevic ${ }^{a}$, M. Bancevic ${ }^{a}$, \\ N.V. Zheleznova ${ }^{b}$, A.Yu. Antipova ${ }^{b}$
}

a Institute of Virology, Vaccine and Sera "Torlak", Belgrade, Serbia

${ }^{b}$ St. Petersburg Pasteur Institute, St. Petersburg, Russian Federation

\begin{abstract}
In 2017, the WHO registered 23,927 measles cases in 44 out of 53 countries in the European region. In 2018, measles incidence rate increased up to 82,599 cases registered in 48 countries of the region, with a large number of measlesassociated deaths. Overall, 72 measles fatalities were registered in 10 European countries, including Serbia (15 cases). Aim of the study: to characterize 2017-2018 epidemiological upsurge of measles incidence rate observed in the Republic of Serbia (RS) and the Northwestern Federal District (NWFD) of the Russian Federation. Materials and methods. During the 2017-2018 season, 944 serum samples were collected from patients with measles, rubella, or exanthematous diseases in the NWFD and tested in the Laboratory of Virology at the St. Petersburg Regional Centre for Measles Surveillance (SPbRC). In 2017-2018, 2,946 serum samples from the Republic of Serbia were analyzed in the SPbRC by using ELISA with IgM measles test system (Vector-Best, Russia; or Siemens, Germany). Urine and swab samples were examined by RT-PCR and used for isolation and genotyping of measles viruses. Results. From 2017 to 2018, 5,798 measles cases were registered in the RS, among which 2,946 were laboratory-confirmed (serological testing and/or PCR). Unvaccinated subjects or those with unknown vaccination status accounted for majority of the cases. Children under 5 years of age and adults aged 30 years and over dominated among measles patients. During this season, 15 deaths were reported. Several genotypes of measles virus circulated in the RS, e.g. B3 Dublin, D8 Gir Somnath, and D8 Herborn. In 2018, 109 measles cases were recorded in the NWFD, 5 of which were imported from abroad. Among patients, adults comprised $64.2 \%$, wherein $74.3 \%$ were covered by unvaccinated subjects or those with unknown vaccination status. Rise in measles incidence rate linked to multiple importations of various measles virus genotypes: B3 Kabul; B3 Dublin; D8 Frankfurt; D8 Cambridge; and D8 Gir Somnath.
\end{abstract}

Key words: incidence, measles, Serbia, Northwest Russia, vaccination, genotypes.

\section{ПОДЬЕМ ЗАБОЛЕВАЕМОСТИ КОРЬЮ В РЕСПУБЛИКЕ СЕРБИЯ И НА СЕВЕРО-ЗАПАДЕ РОССИИ В 2017-2018 ГОДАХ}

Стоилькович В. ${ }^{1}$, Бичурина М.А. ${ }^{2}$, Лаврентьева И.Н. ${ }^{2}$, Филипович-Вигньевич С. ${ }^{1}$, Банчевич М. ${ }^{1}$, Железнова Н.В. ${ }^{2}$, Антипова А.Ю. ${ }^{2}$

${ }^{1}$ Институт вирусологии, вакцин и сывороток «Торлак», Белград, Сербия

${ }_{2}^{2}$ ФБУН НИИ эпидемиологии и микробиологи имени Пастера, Санкт-Петербург, Россия

Резюме. В 2017 г. в Европейском регионе ВОЗ было зарегистрировано 23927 случаев кори в 44 из 53 стран, а в 2018 г. заболеваемость корью возросла до 82599 случаев, которые регистрировались в 48 странах региона. Впервые в 2018 г. имело место большое количество летальных случаев, обусловленных корью. Всего было

\author{
Адрес для переписки: \\ Антипова Анастасия Юрьевна \\ 197101, Россия, Санкт-Петербург, ул. Мира, 14, \\ ФБУН НИИ эпидемиологии и микробиологии имени Пастера. \\ Тел.: 8 (812) 232-94-11 (служебн.). Факс: 8 (812) 233-20-92. \\ E-mail: anti130403@mail.ru
}

\section{Библиографическое описание:}

Стоилькович В., Бичурина М.А., Лаврентьева И.Н., Филипович-

Вигньевич С., Банчевич М., Железнова Н.В., Антипова А.Ю. Подъем заболеваемости корью в Республике Сербия и на Северо-Западе

России в 2017-2018 годах // Инфекция и иммунитет. 2020. Т. 10, № 4.

C. $729-734$. doi: $10.15789 / 2220-7619-R I M-1342$

\section{Contacts:}

Anastasiya Yu. Antipova

197101, Russian Federation, St. Petersburg, Mira str., 14,

St. Petersburg Pasteur Institute.

Phone: +7 (812) 232-94-11 (office). Fax: +7 (812) 233-20-92.

E-mail: anti130403@mail.ru

Citation:

Stoiljkovic V., Bichurina M.A., Lavrentieva I.N., Filipovic-Vignjevic S.,

Bancevic M., Zheleznova N.V., Antipova A.Yu. Rise in 2017-2018 measles morbidity in Serbia and Northwest Russia // Russian Journal of Infection and Immunity = Infektsiya i immunitet, 2020, vol. 10, no. 4, pp. 729-734. doi: 10.15789/2220-7619-RIM-1342 
зарегистрировано 72 случая смерти от кори в десяти странах Европейского региона, включая Сербию (15 случаев). Цель исследования: характеристика эпидемиологического подъема заболеваемости корью в Республике Сербия (РС) и на территориях Северо-Западного федерального округа России (СЗФО) в 2017-2018 гг. Maтериалы и методы. Из Северо-Западного федерального округа в 2017-2018 гг. были исследованы 944 образца сыворотки крови от пациентов с корью, краснухой и экзантемными заболеваниями, доставленные в вирусологическую лабораторию Санкт-Петербургского регионального центра (РЦ). Из Республики Сербия в 2017-2018 гг. были исследованы 2946 образцов сывороток крови. Тестирование образцов сывороток крови проводили методом ИФА, с применением тест-систем IgM-корь фирмы «Вектор-Бест» (Россия) или «Siemens» (Германия). Образцы мочи и носоглоточных смывов исследовались методом RT-PCR и использовались для выделения и генотипирования вирусов кори. Результаты. В Республике Сербия в 2017-2018 г. было зарегистрировано 5798 случаев кори. Лабораторно диагноз подтвержден (серологически и/ или ПЦР) у 2946 пациентов. Болели в основном невакцинированные лица и лица с неизвестным вакцинным статусом. Большинство заболевших были дети моложе пяти лет и взрослые в возрасте 30 лет и старше. В течение этого периода было зарегистрировано 15 летальных случаев. В 2017-2018 гг. в Республике Сербия циркулировали несколько генотипов вируса кори: B3 Dublin, D8 Gir Somnath и D8 Herborn. В Северо-Западном федеральном округе России в 2018 г. было зарегистрировано 109 случаев кори, пять из которых были импортированы из других стран. Среди заболевших лиц 64,2\% составляли взрослые. В 74,3\% случаев болели невакцинированные или лица с неизвестным вакцинным статусом. Повышение заболеваемости корью в СЗФО была связана с многократным импортом различных генотипов вируса кори: B3 Kabul, B3 Dublin, D8 Frankfurt, D8 Cambridge and D8 Gir Somnath.

Ключевые слова: заболеваемость, корь, Сербия, Северо-Запад России, вакцинация, генотипы.

\section{Introduction}

In 2002, the WHO Regional Office for Europe developed a Strategic Plan for the elimination of measles, rubella, and congenital rubella by the end of 2010 [20]. Later, due to increases in measles incidence, the plan's implementation target was postponed until the year 2015 and yet again until the year 2020 [13, 22]. In 2017, 23,927 cases were registered in 44 out of 53 countries in the WHO European region. In 2018, measles incidence increased to 82,599 cases and was registered in 48 countries of the region $[8,14]$. The most affected countries were Ukraine $(53,218$ cases, a rate of $1,209.2$ per million population); Serbia (5,076 cases, a rate of 579.3); Georgia (2,203 cases, a rate of 563.8); and Israel (2,919 cases, a rate of 345.3). In 2018, five WHO European region countries accounted for $81 \%$ of the region's reported measles cases; these were Ukraine, Serbia, Israel, France, and Italy $[6,9,16,24]$. The measles virus was absent in only five regional countries. A large number of fatal measles cases took place for the first time in 2018. Specifically, 72 deaths from measles were recorded in 10 European region countries. The largest numbers of deaths were reported in Romania (22); Ukraine (15); and Serbia (15). Among the sick, $47 \%$ were unvaccinated, and $26 \%$ were of unknown vaccination status. The most affected were persons aged 20 years and over. In 2019, registration of a larger number of measles cases continued in the WHO European region. Cases were registered in Romania $(1,533)$; France $(1,453)$; Poland $(1,044)$; Bulgaria (866); and Italy (864). Seven fatalities occurred: 5 inRomania; 1 inItaly; and 1 inFrance [11].

In the Russian Federation, the 'National Program for Elimination of Measles, Rubella, and Congenital Rubella By The Year 2010' was developed in 2002.
From 2008 to 2010 in Russia, measles incidence was kept at a very low level and cases mainly arose from importation of measles virus (of various genotypes) from endemic regions of the world [2, 3, 4]. The Northwestern Russian Region (NRR) is comprised of 11 areas monitored by the St. Petersburg Regional Centre for Measles Surveillance (SPbRC). From 2008 to 2011, sporadic, individual measles cases were registered in the NRR. In 2012, however, an increase in measles incidence took place in the NRR in connection with a measles outbreak in a children's hospital in St. Petersburg [1]. The goal of WHO-supported epidemiological and laboratory surveillance of measles and rubella in the Republic of Serbia is elimination of endemic measles and rubella; and prevention of congenital rubella infection (CRI) in the European Region [20]. Unfortunately, based on conclusions reached at the $8^{\text {th }}$ meeting of the European Regional Verification Commission for Measles and Rubella Elimination (RVC, 12-14 June 2019, Warsaw), Serbia remains a measles and rubella endemic country. The World Health Organization (WHO) has targeted measles for elimination by 2020 , and the goal does not currently appear to be feasible [13, 22].

Surveillance of measles and rubella in Serbia (population of about 7 million) is conducted by "Dr. Milan Jovanović Batut" Institute of Public Health of Serbia and the National Reference Laboratory for Measles and Rubella (NRL) (of the Torlak Institute of Virology, Vaccine and Sera). Surveillance, based on the WHO measles case definition, was implemented in 2009 and relies on 22 Institutes of Public Health (IPH), the National Reference Laboratory for measles, and healthcare workers (HCWs) at all levels. The epidemiological data analyzed herein originated from public data (regarding the actual epi- 
demiological measles situation in Serbia) provided by the "Dr. Milan Jovanović Batut" Institute of Public Health of Serbia (Belgrade); and from the laboratory database of the National Reference Laboratory for Measles and Rubella. Joint efforts (National Verification Commission, National Reference Laboratory for Measles and Rubella) to eliminate (and maintain elimination) of measles and rubella focus on confirming the absence of transmission of wild measles/rubella viruses in the population or region over defined time periods.

Aim of the study is to characterize increases in measles incidence seen in Serbia and Northwestern Russia from 2017 to 2018.

\section{Materials and methods}

\section{Russian Federation}

Analysis of measles incidence was based on the State Statistical Monitoring Form No. 2 and realtime daily and weekly reports.

Materials. Blood samples were collected from ill patients (between 4 and 7 days after onset of rash) and sent from the region to the SPbRC Laboratory of Virology. Nasal swabs, throat swabs, and/or urine samples were collected (within three days after the onset rash) and delivered to the National Laboratory for Measles and Rubella Diagnostics (of Gabrichevsky Research Institute of Epidemiology and Microbiology, Moscow). In 2017-2018, a total of 944 serum samples from patients ill with measles, rubella, or exanthematous diseases were delivered to the SPbRC.

Methods. Analysis of serum samples was carried out by ELISA using an IgM measles test system (Vector-Best, Russia). At the virological laboratory of the National Research Center (NRC, Russia) for measles and rubella surveillance, 54 samples from patients with a confirmed "measles-positive" diagnosis were further tested by molecular-genetic methods (PCR and sequencing).

\section{The Republic of Serbia}

Case definitions. A suspected measles case was defined as one which matches the following clinical criteria: generalized, maculopapular rash lasting more than 3 days; temperature $\geq 38.3^{\circ} \mathrm{C}$; cough; coryza; conjunctivitis. Measles cases were classified according to WHO criteria $[9,10]$, using the categories: clinically-compatible, epidemiologically-linked, or laboratory-confirmed; as well as definition by origin (endemic, imported, import-related, or unknown). Laboratory-confirmed measles was defined as a case that meets the clinical case definition and has laboratory data (positive for measles-specific IgM antibodies in the blood, and/or measles RNA detected in nose/ throat swabs by PCR). Epidemiologically-linked was defined as a case which meets the clinical case definition and is linked to a laboratory-confirmed case.
Sample collection and laboratory testing. From October 2017 to June 2019, 5,789 patients were recorded; of those, 2,946 were confirmed by laboratory analysis [5]. Sera were collected within 21 days, and nose/throat swabs within 5 days after onset of rash. Laboratory analysis included detection of measlesspecific IgM antibodies using an enzyme-linked immunosorbent assay (ELISA) $\left(\right.$ Enzygnost $^{\circledR}$, Siemens Healthcare Diagnostic Products GmbH, Marburg, Germany) and/or detection of measles RNA in nose/ throat swabs by real-time PCR. Briefly, RNA was extracted from $140 \mu$ of nose/throat swab samples using the QIAamp viral RNA kit (Qiagen, Hilden, Germany) according to the manufacturer's instructions. Using primers and probes from the Statens Institute (Denmark), amplification was done in a $25 \mu \mathrm{l}$ volume containing $5 \mu \mathrm{l}$ of extracted RNA and $20 \mu \mathrm{l}$ of master mix; an Mx3005P (Stratagene) instrument was used for thermal cycling. Serological and molecular analyses were performed at the $\mathrm{Na}$ tional Measles/Rubella Reference Laboratory of the Torlak Institute of Virology, Vaccine and Sera.

Phylogenetic Analysis. Clinical samples (nasal/ throat swabs) from 125 measles-positive patients (as determined by PCR) were sent to the WHO European Regional Reference Laboratory (Luxembourg) for sequencing and genotyping. Using molecular evolutionary genetics analysis software [18] with recommended reference sequences [21, 23], a neighbour-joining phylogenetic tree, based on the Kimura two-parameter method, was constructed. Specifically, 450 nucleotides, which encode the carboxyl-terminal 150 amino acids of the measles virus nucleoprotein, were analyzed. Statistical analysis of the data was carried out using the Student's t-test.

\section{Results and discussion}

The SPbRC serves 11 administrative regions located in Northwestern Russia. Collectively, they represent approximately 14 million people. Measles incidence in Northwestern Russia has featured surges and falls since the year 2000 (fig. 1).

During the 2007-2011 period, sporadic imported measles cases were recorded in the district. In 2012, an upsurge in measles incidence took place due mostly to transfer of measles infection to a pediatric hospital in St. Petersburg; there, a focus of measles infection formed totaling 94 cases [1]. Several conditions were conducive to the spread of infection within the hospital: late diagnosis and isolation of the first patient with measles; placement of the afflicted patient in a unit with a majority of non-vaccinated (because of their age or health status) children; and movement of the patient within the hospital for diagnostic and treatment procedures.

Later, the number of cases decreased, leading to a complete absence of measles in 2016. An upsurge in measles incidence took place in 2018. In total, 109 


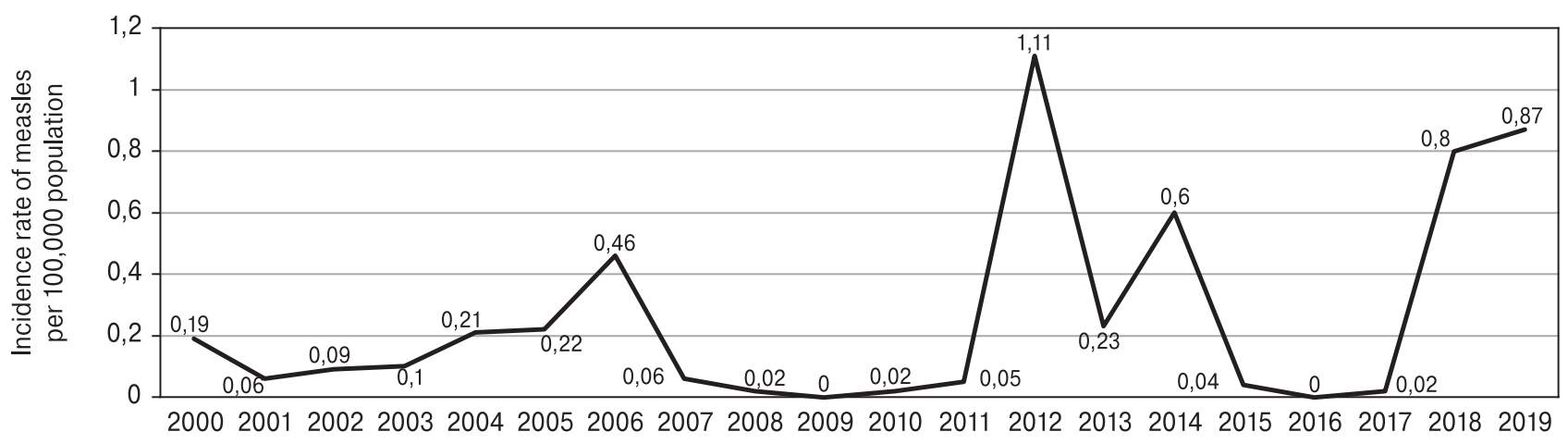

Figure 1. Incidence of measles in the Northwest Federal District of Russia, 2000-2019 (per 100,000 population)

cases were recorded, and the incidence rate was 0.79 per 100,000 population. Measles was registered in 6 out of 11 regions, and the largest number of cases were reported in three regions: Saint Petersburg 54 cases (1.02 per 100,000 population); Leningrad Region - 21 cases (1.22 per 100,000 population); and the Republic of Karelia - 29 cases (4.62 per 100,000 population). In 2018, five imported cases were registered from Italy, France, Turkey, and Ukraine. In addition, 25 measles cases were imported from other Russian regions. The largest number of cases were from three areas of the North Caucasian Federal District: the Republic of Dagestan; the Republic of Ingushetia; and the Chechen Republic.

In St. Petersburg, 3 foci of nosocomial transmission and 3 foci of familial infection occurred. In the Leningrad Region (the area surrounding, but not including St. Petersburg), two foci of familial infection were seen. In addition, a measles outbreak (29 cases) occurred in the Republic of Karelia which lasted for a month; mass illness started in late June 2018, and the last case was recorded on July 23. The cause behind the intense measles incidence in the Republic was a missed measles case in the middle of June. The patient received a diagnosis of "enterovirus infection" and was not tested for measles. Among the affected were 5 non-vaccinated medical workers at a district hospital and 5 measles cases due to visits to a clinic. The age structure of measles patients

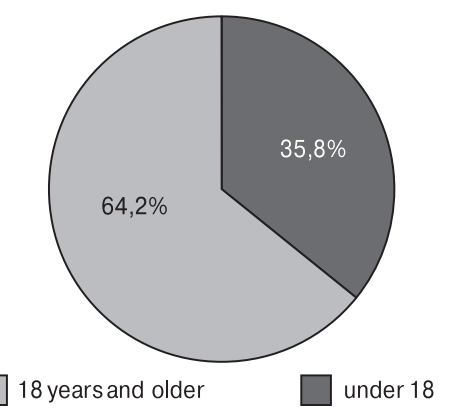

Figure 2. Age structure of measles patients in regions served by the SPbRC, 2018 in regions served by the $\mathrm{SPbRC}$, for 2018, is presented in figure 2. Children represented $35.8 \%$ of the affected patients.

Analysis of patients' vaccination status showed that the afflicted were predominantly in the category of "unvaccinated, or of unknown vaccination status" (74.3\%). In addition, among the affected persons known to have received vaccination, cases were as follows: $6.4 \%$ were patients who had been covered by one-dose vaccine; and $18.4 \%$ were people who had been covered by two-dose vaccine (fig. 3 ).

Molecular-genetic analysis showed that different genotypes of measles virus were detected from $\mathrm{SPbRC}$ regions. In St. Petersburg, the genotypes B3 Kabul, B3 Dublin, D8 Frankfurt, D8 Cambridge, and D8 GirSomnath were detected. Cases in the Leningrad Region featured D8 Frankfurt, and the measles outbreak in The Republic of Karelia was due to the D8 GirSomnath genotype. These data indicate multiple importations of various measles genotypes from abroad, as well as from other Russian regions.

In the Republic of Serbia, following several years of very low immunization coverage (two-dose MMR vaccine), cases began to rise. From early October 2017 to June 2019 in Serbia (including regions served by the National Institute of Public Health of Kosovo, Mitrovica), 5,798 measles cases were recorded, of which 2,946 were laboratory confirmed [5, 12]. At the end of December 2017, the first measles death was reported in the Republic of Serbia in 20 years. By the end of April 2018, another 14 deaths due to measles had been reported. Out of the total number of patients, $33 \%$ were hospitalized. Regarding serious complications of measles, 2 patients had brain inflammation and 587 patients were diagnosed with pneumonia. The most affected groups were children under 5 years of age and adults aged 30 and over. The youngest patient was 15 days old, and the oldest was 71 years old. Nearly $95 \%$ of the patients were either unvaccinated, incompletely-vaccinated, or of unknown vaccination status. The main strain of the measles virus was the genotype B3 Dublin variant. Sequence data identified the genotype B3, Dublin variant in 123 nose/ throat swab samples. In one patient from Novi Sad, 
the D8 genotype (GirSomnath variant, import case) was detected. In another patient from Pancevo, the D8 genotype (Herborn variant, import case) was detected.

Mandatory measles immunization with a single monovalent dose, targeting all children aged 1215 months, was introduced in Serbia in 1971. The bivalent measles-mumps vaccine was introduced into the immunization program in 1981. In 1993, bivalent MM vaccine was replaced with a combined measles-mumps-rubella (MMR) vaccine. From 1994, the trivalent MMR vaccine began to be delivered using a two-dose schedule: once at the age of 12-15 months; and once at 12 years of age. The second dose was moved to preschool age (6-7 years) in 2006, and if the child misses the second dose, he/she is to be re-vaccinated before the age of 15 years. Over the last seven years, full MMR coverage (both doses received) has been below $95 \%$ [15, 19]. Vaccination coverage for second dose MMR vaccine in last ten years was significantly lower than $95 \%$. In 2017, the rates were: $1^{\text {st }}$ dose $-85.2 \%$ and $2^{\text {nd }}$ dose $-91.6 \%$.

Following the introduction of measles vaccination in Serbia in 1971, the disease has appeared in epidemic form every 3 to 5 years, but with a much smaller number of cases compared to the period before the introduction of the vaccine. Large outbreaks were registered in 1986, 1989, 1993, 1997, 2007, 2011, and 2015 $[7,17]$. Only a few sporadic measles cases were reported between these outbreaks. In Serbia, there were no recorded measles-associated deaths in the time period from the 1997 measles outbreak (which affected approximately 4,000 people) until December 2017.

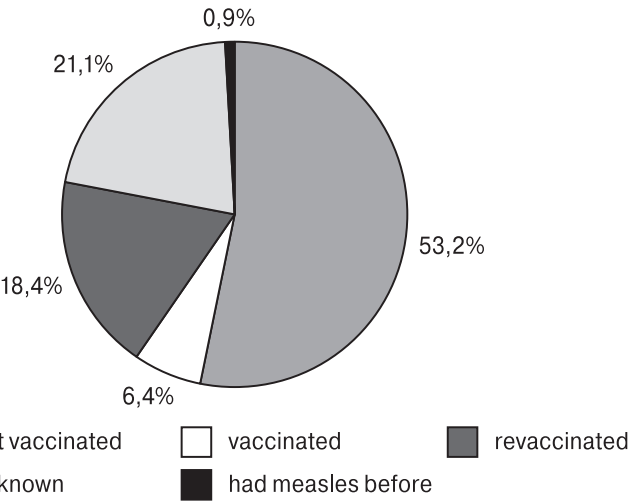

\section{Figure 3. Distribution of measles patients by vaccination status in the regions served by the SPbRC, 2018}

Since 2013, there has been a growing, vocal antivaccination movement and a consequent rejection of immunization by some parents. This, combined with high-risk populations who remain outside of the immunization system, has led to a critical mass of unvaccinated individuals that disrupts the collective immunity of the population. In light of these facts, elimination of measles on a global scale will require synchronized efforts in several key areas: maintenance of sustained, high levels of routine immunization (95\% or above); enactment of additional immunization campaigns for risk groups (including certain healthcare workers); and activities to counter the anti-vaccination lobby.

\section{References}

1. Бичурина М.А., Тимофеева Е.В., Железнова Н.В., Игнатьева Н.А., Шульга С.В., Лялина Л.В., Дегтярев О.В. Вспышка кори в детской больнице Санкт-Петербурга в 2012 году // Журнал инфектологии. 2013. Т. 5, № 2. С. 96-102. [Bichurina M.A., Timofeeva E.V., Zheleznova N.V., Ignat'eva N.A., Shul'ga S.V., Lyalina L.V., Degtyarev O.V. Measles outbreak in a children's hospital in Saint Petersburg in 2012. Zhurnal infektologii = Journal Infectology, 2013, vol. 5, no. 2, pp. 96-102. (In Russ.)]

2. Результаты сертификации территорий СЗФО на отсутствие циркуляции эндемичного вируса кори: Аналитический обзор. СПб.: ФБУН НИИЭМ имени Пастера, 2012. 60 с. [Results of certification of the territories of NFD for the absence of endemic measles virus circulation: analytical review. St. Petersburg: St. Petersburg Pasteur Institute, 2012. 60 p. (In Russ.)]

3. Совершенствование эпидемиологического надзора за корью в Северо-Западном федеральном округе России на этапе ликвидации инфекции: Аналитический обзор. ФБУН НИИЭМ имени Пастера, 2008. 52 c. [Improving epidemiological surveillance for measles in the Northwestern Federal District of Russia at the stage of infection elimination: analytical review. St. Petersburg: St. Petersburg Pasteur Institute, 2008. 52 p. (In Russ.)]

4. Шульга С.В., Тихонова Н.Т., Наумова М.А. Изменение спектра циркулирующих генотипов вируса как показатель элиминации индигенной кори в России // Эпидемиология и вакцинопрофилактика. 2009. № 4. C. 4-9. [Shulga S.V., Tikhonova N.T., Naumova M.A. Change the spectrum of circulating genotypes of the virus as index of elimination of the indigenous measles in Russia. Epidemiologiya i vaktsinoprofilaktika = Epidemiology and Vaccinal Prevention, 2009, no. 4, pp. 4-9. (In Russ.)]

5. Actual epidemiological situation of measles in Serbia. Belgrade: Institute of Public Health of Serbia, 2019. URL: http://www.batut. org.rs/index.php?content $=1629$ (03.08.2019).

6. Andrianou X.D., Del Manso M., Bella A., Vescio M.F., Baggieri M., Rota M.C., Pezzotti P., Filia A. Spatiotemporal distribution and determinants of measles incidence during a large outbreak, Italy, September 2016 to July 2018. Euro Surveill., 2019, vol. 24, no. 17: 1800679. doi: 10.2807/1560-7917.ES.2019.24.17.1800679

7. Annual report on the immunization in the Republic of the Serbia in 2011. Belgrade: Institute of Public Health of Serbia. URL: http://www.batut.org.rs/download/izvestaji/Rezultati\%200\%20sprovedenoj\%20imunizaciji\%202011 (03.08.2019).

8. Filia A., Bella A., Del Manso M., Baggieri M., Magurano F., Rota M.C. Ongoing outbreak with well over 4,000 measles cases in Italy from January to end August 2017 - what is making elimination so difficult? Euro Surveill., 2017, vol. 22, no. 37 : 30614. doi: 10.2807/1560-7917.ES.2017.22.37.30614

9. Manual for the laboratory-based surveillance of measles, rubella, and congenital rubella syndrome. $3^{\text {rd }}$ ed. WHO, 2018. URL: https://www.who.int/immunization/monitoring_surveillance/burden/laboratory/manual/en (15.12.2019). 
10. Manual for the laboratory diagnosis of measles and rubella virus infection. $2^{\text {nd }}$ ed. Geneva: WHO, 2006. $22 \mathrm{p}$.

11. Measles update. Bulletin WHO. June 14, 2019. URL: https://www.who.int/csr/don/06-may-2019-measles-euro/en (08.10.2019).

12. Nedeljković J., Rakić Adrović S., Tasić G., Kovačević-Jovanović V., Lončarević G., Hübschen J.M., Muller C.P. Resurgence of measles in Serbia 2010-2011 highlights the need for supplementary immunization activities. Epidemiol. Infect., 2016, vol. 144, no. 5, pp. 1121-1128. doi: 10.1017/S0950268815002277

13. Orenstein W.A., Hinman A., Nkowane B., Olive J.M., Reingold A. Measles and rubella global strategic plan $2012-2020$ midterm review. Vaccine, 2018, vol. 36, suppl. 1, pp. A1-A34. doi: 10.1016/j.vaccine.2017.09.026

14. Orosz L., Gáspár G., Rózsa Á., Rákos N., Sziveri S., Bosnyákovits T. Epidemiological situation of measles in Romania, Italy, and Hungary: On what threats should we focus nowadays? Acta Microbiol. Immunol. Hung., 2018, vol. 65, no. 2, pp. 127-134. doi: 10.1556/030.65.2018.014

15. Report on immunization conducted on the territory of the Republic of Serbia in 2018. URL: http://www.batut.org.rs/index. php?content $=1900$ (In Serb.)

16. Ristić M., Milošević V., Medić S., Djekić Malbaša J., Rajčević S., Boban J., Petrović V. Seroepidemiological study in prediction of the risk groups for measles outbreaks in Vojvodina, Serbia. PLoS One, 2019, vol. 14, no. 5: e0216219. doi: 10.1371/journal. pone. 0216219

17. Šeguljev Z., Đurić P., Petrović V., Stefanović S., Ćosić G., Hrnjaković I.C., Milošević V., Karagiannis I., Boxall N., Jankovic D. Current measles outbreak in Serbia: a preliminary report. Euro Surveill., 2007, vol. 12, no. 11: E070315.2. doi: 10.2807/ esw.12.11.03155-en

18. Tamura K., Stecher G., Peterson D., Filipski A., Kumar S. MEGA 6: molecular evolutionary genetics analysis version 6.0. Mol. Biol. Evol., 2013, vol. 30, no. 12, pp. 2725-2759. doi: 10.1093/molbev/mst197

19. The results of conducted immunization in the Republic of Serbia in 2015-2016. Belgrade: Institute of Public Health of Serbia, 2016. $57 p$. (In Serb.)

20. World Health Organization. Eliminating measles and rubella and preventing congenital rubella infection: WHO European Region strategic plan 2005-2010. URL: http://www.euro.who.int/__data/assets/pdf_file/0008/79028/E87772.pdf.

21. World Health Organization. Genetic diversity of wild-type measles viruse and the global measles nucleotide surveillance database (MeaNS). Wkly Epid. Rec., 2015, vol. 90, no. 30, pp. 373-380.

22. World Health Organization. Global Vaccine Action Plan 2011-2020. URL: http://www.who.int/immunization/global_vaccine_action plan/GVAP doc 2011 2020/en

23. World Health Organization. Measles virus nomenclature update: 2012. Wkly Epid. Rec., 2012, vol. 87, no. 9, pp. 73-80.

24. Zimmerman L.A., Muscat M., Singh S., Ben Mamou M., Jankovic D., Datta S., Alexander J.P., Goodson J.L., O’Connor P. Progress Toward Measles Elimination - European Region, 2009-2018. MMWR, 2019, vol. 68, no. 17, pp. 396-401.

\section{Авторы:}

Стоилькович В.Д., и.о. директора Института вирусологии, вакцин и сывороток «Торлак», Белград, Сербия;

Бичурина М.А., д.м.Н., зав. вирусологической лабораторией центра по элиминации кори и краснухи ФБУН НИИ эпидемиологии и микробиологии имени Пастера, Санкт-Петербург, Россия;

Лаврентьева И.Н., д.М.н., зав. лабораторией экспериментальной вирусологии ФБУН НИИ эпидемиологии и микробиологии имени Пастера, Санкт-Петербург, Россия; Филипович-Вигньевич С.Б., ассистент директора по диагностике и научному развитию, руководитель Национальной референс-лаборатории по гриппу Института вирусологии, вакцин и сывороток «Торлак», Белград, Сербия; Банцевич М.Д., д.м.н., специалист в области медицинской микробиологии, зав. Национальной референс-лабораторией по кори и краснухе отдела серологии и молекулярной диагностики Института вирусологии, вакцин и сывороток «Торлак», Белград, Сербия;

Железнова Н.В., к.б.н., ведущий научный сотрудник лаборатории вирусных гепатитов ФБУН НИИ эпидемиологии и микробиологии имени Пастера, Санкт-Петербург, Россия;

Антипова А.Ю., к.б.н., старший научный сотрудник лаборатории экспериментальной вирусологии ФБУН НИИ эпидемиологии и микробиологии имени Пастера, Санкт-Петербург, Россия.

\section{Authors:}

Stoiljkovic V.D., Acting Mananging Director of Institute for Virology, Vaccine and Sera "Torlak", Belgrade, Serbia;

Bichurina M.A., PhD, MD (Medicine), Head of the Virological Laboratory of Measles and Rubella Elimination, St. Petersburg Pasteur Institute, St. Petersburg, Russian Federation; Lavrentieva I.N., PhD, MD (Medicine), Head of the Laboratory of Experimental Virology, St. Petersburg Pasteur Institute, St. Petersburg, Russian Federation;

Filipovic-Vignjevic S.B., Director Assistant for Diagnostics and Scientific Development, Head of National Reference Laboratory for Influenza, Institute for Virology, Vaccine and Sera "Torlak", Belgrade, Serbia;

Bancevic M.D., PhD, MD (Medicine), Specialist in Medical Microbiology, Head of National Reference Laboratory for Measles and Rubella, Department of Serology and Molecular Diagnostics, Institute for Virology, Vaccine and Sera "Torlak", Belgrade, Serbia Zheleznova N.V., PhD (Biology), Leading Researcher, Laboratory of Viral Hepatitis, St. Petersburg Pasteur Institute, St. Petersburg, Russian Federation;

Antipova A.Yu., PhD (Biology), Senior Researcher, Laboratory of Experimental Virology, St. Petersburg Pasteur Institute, St. Petersburg, Russian Federation.
Поступила в редакцию 10.12.2019

Отправлена на доработку 16.01.2020

Принята к печати 11.03.2020
Received 10.12.2019

Revision received 16.01.2020

Accepted 11.03.2020 